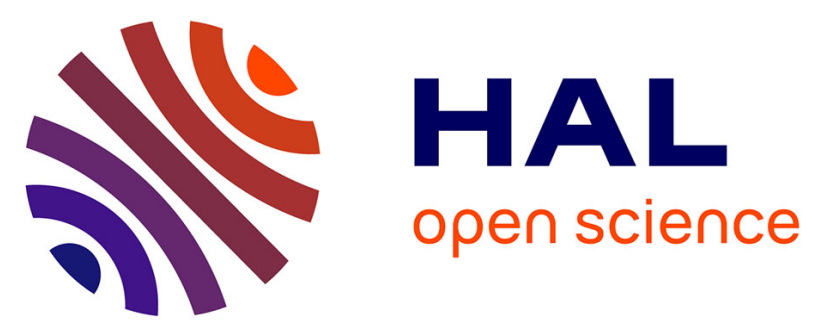

\title{
Use of multivariate analyses to investigate the contribution of metal pollution to diatom species composition: search for the most appropriate cases and explanatory variables
}

H. Guasch, M. Leira, B. Montuelle, A. Geizinger, J.L. Roulier, E. Tornes, A. Serra

\section{To cite this version:}

H. Guasch, M. Leira, B. Montuelle, A. Geizinger, J.L. Roulier, et al.. Use of multivariate analyses to investigate the contribution of metal pollution to diatom species composition: search for the most appropriate cases and explanatory variables. Hydrobiologia, 2009, 627, p. 143 - p. 158. 10.1007/s10750-009-9721-0 . hal-00473168

\section{HAL Id: hal-00473168 https://hal.science/hal-00473168}

Submitted on 14 Apr 2010

HAL is a multi-disciplinary open access archive for the deposit and dissemination of scientific research documents, whether they are published or not. The documents may come from teaching and research institutions in France or abroad, or from public or private research centers.
L'archive ouverte pluridisciplinaire HAL, est destinée au dépôt et à la diffusion de documents scientifiques de niveau recherche, publiés ou non, émanant des établissements d'enseignement et de recherche français ou étrangers, des laboratoires publics ou privés. 
1 Use of multivariate analyses to investigate the contribution of metal pollution to diatom species

2 composition: search for the most appropriate cases and explanatory variables

4 Helena Guasch ${ }^{\mathrm{a},{ }^{*}}$, Manel Leira ${ }^{\mathrm{b}}$, Bernard Montuelle ${ }^{\mathrm{c}}$, Anita Geiszinger ${ }^{\mathrm{a}}$, Jean Luis Roulier ${ }^{\mathrm{c}}$,

5 Elisabet Tornés ${ }^{\mathrm{a}}$, Alexandra Serra ${ }^{\mathrm{a}}$

6 'anstitut d'Ecologia Aquàtica, Facultat de Ciències, Campus Montilivi, 17071, Girona, Spain

$7 \quad{ }^{b}$ Faculty of Sciences, University of A Coruña, Campus da Zapateira 15071, A Coruña, Spain

$8{ }^{\mathrm{c}}$ Cemagref, Research Unit Water Quality, 3 bis quai Chauveau, CP220, F-69336 Lyon cedex 09,

9 France

11 Abstract

The aim of this study was to elucidate how the spatial scale and the set of variables

13 included influence our ability to detect the effects of different types of pollution on the biota.

14 Using variance partitioning analysis we assessed the individual importance of a set of

15 environmental factors (eutrophication and organic pollution) versus metal level pollution on the community structure of diatom assemblages at different spatial scales. At regional scale environmental factors did not explain more of the variance compared to the watershed study. The results of the watershed scale field survey indicate that diatom community composition was

19 influenced by low metal concentrations but this pattern was only observed by the inclusion of

20 biofilm metal concentration data. We recommend the analysis of metal traces in the water phase and the biota (fluvial biofilms) as well as the use of the Diffusive Gradient in Thin films (DGT) technique to characterize low metal level pollution in freshwater systems. 


\section{Introduction}

The scale-dependence of ecological patterns and processes has been widely recognized by freshwater ecologists, current knowledge of scale effects on monitoring networks is still insufficient. Furthermore, this might be a complicated task in polluted rivers with different types of pollution occurring simultaneously. The recognition of what factors structure benthic communities at different spatial scales is also necessary for water policy makers. In the case of Europe, this knowledge will contribute to the implementation of the European Water Framework Directive (WFD) (Directive 2000/60/EC). The WFD is an important piece of legislation aiming to achieve a "good ecological quality" for all waters in the EU by 2015.

Pollution and monitoring programmes routinely include the examination of diatoms to investigate the ecological status of fluvial systems (Kelly et al., 1998; Prygiel et al., 2002, Jüttner et al., 2003). It is also recognised diatoms sensitivity to high metal pollution as has been shown in watersheds draining mining areas (Ivorra et al., 1999; Hirst et al., 2002; Nunes et al., 2003; Gold et al., 2003) but also to low metal pollution as described under experimental conditions (Paulsson et al., 2000; Guasch et al., 2002). However, there are few studies relating diatom species composition with metal pollution in fluvial systems draining urban areas or receiving Waste Water Treatment Plant (WWTP) outfalls. The simultaneous occurrence of low metal pollution with eutrophication and organic pollution, may confound the specific effects of metal pollution on diatom communities (Rogers et al., 2002; Hirst et al., 2002; Boisson \& Perrodin, 2006).

Significant increases in surface water metal concentration can occur in the vicinity of WWTP outfalls and due to urban runoff. In this context, the usual approach used in most of the stream monitoring programs might be confounded by spatial variation, therefore limiting our ability to separate the effect of all sources of human disturbance. Sediments play an important role in reducing water column concentrations following effluent release. The dominance of adsorption and complexation processes in natural systems means that most trace metals are rapidly incorporated within bottom sediments (Bubb \& Lester, 1995). Consequently, monitoring 
programs based on water metal concentration may fail to detect this type of pollution if data

concerning metal content in the bottom sediments and biota are not considered.

Particularly, metal concentration in periphyton has been related with metal pollution, but it may also be modulated by differences in metal speciation (Meylan et al., 2003). Metal speciation is a matter of interest as it controls toxicity: assessment of total, dissolved and free (ions) metals is thus needed for understanding the real exposition of organisms. Diffusive Gel in Thin films (DGT) has been proposed as a technique capable of measuring metal speciation "in situ". The main aim of this study was to elucidate the confounding effects of spatial variation in community structure in order to determine the influence of low metal pollution on the ecological status of fluvial systems. Our specific objectives were to i) describe the pollution gradient and the corresponding diatom community at regional scale, ii) obtain a good characterization of metal loads and metal availability in a watershed chronically exposed to low metal pollution and iii) investigate, at both scales, the relative contribution of different types of pollution: eutrophication and organic pollution vs. metal pollution to diatom species composition using variance partitioning multivariate analyses

\section{Methods}

Multivariate analysis were applied to two different data-sets, one covering a large area (referred to as regional study) and the second restricted to a small watershed (referred to as watershed study). Data used for the regional study was provided by the Catalan Water Agency. The data set aimed to cover a large environmental gradient. Available data included a characterization of water mineralization, nutrient content, water metal concentration and inventories of diatom species from different watersheds influenced mainly by urban, agricultural and industrial activities (Tornés et al., 2007). Furthermore, and due to the limited data available concerning metal pollution at a regional scale, a more detailed sampling was planned in the Fluvià watershed slightly impacted by agricultural, urban and small industrial activities; a continual in situ sampling (time-integrated) followed by analysis in the laboratory was applied using the Diffusive Gradient in Thin films 
(DGT) technique. Metal analysis techniques were also improved (reducing detection limits from $10 \mu \mathrm{g} / \mathrm{L}$ to $0.1 \mu \mathrm{g} / \mathrm{L}$ ); and the analyses of metal concentrations in biofilms was also included.

\subsection{Area of study}

Regional study. Twenty-one sites monitored by the Catalan Water Agency (Catalonia, NE Spain) were included in the regional study. The diversity in morphology, climate and human land uses in the area of study determine an important spatial heterogeneity across the region (Leira \& Sabater, 2005). The sites were selected to cover a large gradient of metal pollution, ranging from pristine to polluted, with different levels of human disturbance (Table 1 and Fig. 1).

Watershed study. The watershed study was carried out in the River Fluvià, a Mediterranean calcareous river in Catalonia (NE Spain). The area of study is located within a volcanic zone (declared Natural Park in 1982) in the upper part of the Fluvià watershed (1080 km2). This study included six sampling sites in the headwater of the River Fluvià and its main tributaries (Fig. 1).

In spite of being a mainly forested area (68\% of the surface), the Fluvià watershed is highly influenced by agricultural activities (25\%). The remaining area of the watershed consists of shrub lands $(4 \%)$, built-up space $(2 \%)$, and wetland vegetation $(<1 \%)$. The sampling sites chosen in this study followed a gradient in the dominant land uses from mostly forested area (B1, B2=J070 and T1) to agricultural, urban and industrial uses $(\mathrm{Rd}=\mathrm{J} 105, \mathrm{~T} 2=\mathrm{J} 104, \mathrm{Ol}=\mathrm{J} 013)$. Two sampling sites receive WWTP outflows: Rd urban wastewaters from a small town (Olot, 32,000 inhabitants) and T2 food industry wastewaters (Beguda).

\subsection{Field sampling}

Regional study. Data were obtained from the monitoring program planned by the Catalan Water Agency (ACA) for the assessment of diatom indices during summer (July-August) 2002 and spring (May-June) 2003. Epilithic diatom samples were taken from the riffle sections at sites covering the major types of geomorphological and physiographical conditions (ACA, 2003). At 
least five stones were randomly collected from the stream bottom, and brushed to detach the algal

100 communities to a final area of $2-10 \mathrm{~cm}^{2}$. A pooled sample was obtained from each site.

101 Simultaneously, field physico-chemical variables were measured and site descriptors taken from

102 field observations. Diatom sampling and counting followed the CEN standard protocols (2000,

103 2001). Algal samples were preserved in formaldehyde 4\% (v/v) until analysis.

104 Watershed study. Sampling of the six sites within the Fluvià watershed took place at three 105 different periods: December 2003, February and July 2004. During each sampling period, 106 physico-chemical parameters were measured in the field. Samples of benthic diatoms were taken 107 as for the regional study.

\subsection{Water chemistry}

109 Regional study. Water chemistry of the selected sites was obtained from the Catalan Water 110 Agency (ACA) which monitors them monthly. The following variables were included: 111 conductivity, water hardness, dissolved oxygen, TOC, $\mathrm{NO}_{3}-\mathrm{N}, \mathrm{P}_{2} \mathrm{O}_{5}, \mathrm{SO}_{4}, \mathrm{Cl}, \mathrm{HCO}_{3} ; \mathrm{NH}_{4}-\mathrm{N}, \mathrm{K}$,

$112 \mathrm{Ca}, \mathrm{Na}$ (the most common used for monitoring purposes) and water metal concentration $(\mathrm{Cd}, \mathrm{Cr}$,

$113 \mathrm{Cu}, \mathrm{Pb}, \mathrm{Ni}, \mathrm{Zn}, \mathrm{As}, \mathrm{Hg}$ ). Water samples were analysed following standard procedures (APHA, 114 1989).

115 Watershed study. Physicochemical parameters of each point were taken at 3 sampling dates,

116 December 2003, February and July 2004. At each sampling date, temperature, pH, dissolved

117 oxygen and conductivity were measured in the field using WTW probes, and water samples (1

118 litre per site) were collected and transported refrigerated for their analysis in the laboratory.

119 Samples were filtered by GF/C Whatman glass microfibre filters, refrigerated $\left(4^{\circ} \mathrm{C}\right)$. They where 120 analysed within $24 \mathrm{~h}$ for ammonium measurements and frozen for SRP, nitrate and nitrite analyses 121 following standard procedures (APHA, 1989). Naturally derived DOC is relatively low in the area 122 of study ranging between $1-3 \mathrm{mg} / \mathrm{L}$ (Blanck et al 2003). DOC values above $5 \mathrm{mg} / \mathrm{L}$ are indicative, 123 in this area, of anthropogenic organic pollution. 
Metals in water. Total dissolved metal concentration measurements were carried out in triplicates of water samples collected in the field at each sampling point. Samples were immediately filtered (Whatman nylon filters $0.2 \mu \mathrm{m}$ ) and acidified with nitric acid (Supra pure, 127 Merck; 1\%).

Metals in biofilms. Biofilms were scratched from three different stones randomly collected from the stream bottom at each sampling site by using a clean microscope slide. After the

130 collection, biofilms were lyophilized and weighed. Dry samples were digested with $4 \mathrm{ml}$ of 131 concentrated nitric acid (Supra pure) and $1 \mathrm{~mL}$ of $30 \%$ of hydrogen peroxide in a high performance microwave oven (Milestone, Ethos sel) and were thereafter diluted to $25 \mathrm{~mL}$ with milli-Q water. Metal concentrations of water and biofilm samples were determined by inductively coupled plasma mass spectroscopy (ICP-MS; HP 7500c, Agilent). measuring metal speciation "in situ" (Davison et al. 2000). DGT was applied to measure free and labile copper, which is supposed to be a good estimation of the bioavailable part in the water (Davison and Zhang, 1994). This technique has recently been validated in fluvial systems

139 (Tusseau-Vuillemin et al., 2007).

140 Each DGT device consisted of a plastic base $(2.5 \mathrm{~cm}$ diameter $)$ and a plastic cap with a

$1412 \mathrm{~cm}$ diameter window; this plastic holder was loaded with a filter, a resin gel, a diffusive gel and 142 a second filter. DGT holders (piston type), diffusive gel disks (0.8 mm thick) and Chelex-100

143 binding resins (0.4 mm thick) were purchased from DGT research (Lancaster, UK); nitrate

144 cellulose filter membranes $(0.13 \mathrm{~mm}$ thick; $0.45 \mu \mathrm{m}$ mesh) were purchased from Millipore 145 (Molsheim, France). Three DGTs were deployed at each sampling site (B1, B2, T1, T2, OL, Rd) 146 in two occasions (December and July 04). The DGT holders were placed in a plastic grid role with 147 the window down to avoid sediment settlement on top of them. The grid role was made by a piece 148 of plastic grid (square of $30 * 30 \mathrm{~cm}$ with $4 \mathrm{~cm}$ holes approx.) which was rolled and the DGT 
149 holder was fixed to a small window. The whole device was attached to big stones inside the river

150 during one week. Exact exposure time, temperature, water flow, and $\mathrm{pH}$ were recorded for each

151 sampling site. After exposure, the resin gels were eluted in $7 \mathrm{~mL} 1 \mathrm{M} \mathrm{HNO}_{3}$. Metal concentrations

152 of the DGT resin gel eluates and the acidified $\left(1 \% \mathrm{HNO}_{3}\right)$ water samples were measured by

153 inductively coupled plasma mass spectrometry (ICP-MS; HP 7500c Agilent). The mass of metal

154 sequestered on the DGT resin was evaluated considering an $80 \%$ yield of elution (Zhang et al.

155 1995). Calculations of labile copper were done according to Davison and Zhang (1994). All

156 material used was soaked previously in $10 \% \mathrm{HNO}_{3}$ for $24 \mathrm{~h}$ and rinsed with ultrapure water.

157 2.4. Diatom analyses

158 Diatom frustules were cleaned of organic material by acid oxidation using sulphuric acid,

159 dichromate potassium and hydrogen peroxide. Permanent slides were mounted using Naphrax (r.i.

160 1.74). At least 400 valves were counted on each slide by performing random transects under light

161 microscopy using Nomarski differential interference contrast optics at magnification of $1000 \mathrm{x}$.

162 Taxa were identified mainly according to standard floras (Krammer \& Lange-Bertalot 1991-1997;

163 and Lange-Bertalot 2001).

\section{2.5. Data analysis}

165 Polluted sites are likely to contain a mixture of metals which in turn might have additive effects

166 even at chronic concentration. Consequently, we used a measure of total metal concentration and

167 toxicity; the cumulative criterion unit (CCU; Clements et al., 2000) which has been already

168 applied to analyse the response of different organisms to metals in streams (Clements et al., 2000;

169 Hickey and Golding, 2002; Hirst et al., 2002). However, so far, the CCU is untested in the field in

170 continental Europe. Cumulative criterion unit (CCU) scores were calculated from metal

171 concentrations after EPA (2006) as:

$$
C C U=\sum m_{i} / c_{i}
$$


where $m_{i}$ is the total recoverable metal concentration and $c_{i}$ is the criterion value for the ith metal.

174 The criterion value is based on U.S. EPA guidelines on critical concentrations, which, when

175 exceeded, may harm aquatic organisms. Metals that were below detection were not included in the

176 CCU. Thus, a CCU value of 1.0 represents a conservative estimate of the criterion value for all

177 metals based at any given sampling site. We calculated the relative percentage contribution of

178 each metal to the CCU values to evaluate which metals contribute most to toxicity. We placed the

179 sampling sites into one of three categories based on the measure CCU. Background sites were

180 defined as sites with CCU values below 1.0. Assuming that metal effects are additive, a value of

$181 \quad 1.0$ represents the point at which we would expect to notice adverse effects on the aquatic

182 organisms. The low metal category consisted of those sites with a CCU value between 1.0 and 2.0.

183 The medium metal category consisted of sites with CCU values between 2.0 and 10.0. We

184 selected these cutoff values because we were interested in quantifying the effect of metals at low

185 and moderate concentrations, so the medium level category would be ideal to test if the diatom

186 communities would become tolerant when metal concentrations exceed the limit criterion value by

187 a factor of only 2 or less. As water hardness affects the toxicity and bioavailability of some

188 metals, criterion values for $\mathrm{Cd}, \mathrm{Cu}, \mathrm{Pb}$ and $\mathrm{Zn}$ may vary, and were modified to account for

189 variation in water hardness between sites.

190 Water metal concentration and metal concentrations in the biofilm were also used to

191 calculate cumulative criterion units for the watershed study following the procedures described

192 above and referred to as CCUw and CCUb, respectively. In the case of CCUb, criterion values

193 were not corrected for water hardness due to the lack of information concerning water chemistry

194 in the biofilm. However, differences in metal availability due to hardness are expected to be small

195 since all sites belong to the same geologic area and have similar water hardness.

\subsection{Statistical methods}

197 Physico-chemical variability over time was first explored. In the regional study, temporal 
variability was evaluated by comparing spring and summer average values. In the watershed study, differences between the three sampling times were evaluated using ANOVA using the time as a factor.

Multivariate techniques (ter Braak \& Verdonschot, 1995) allow the elucidation of ecological factors, which may explain the variation in diatom communities. Constrained ordination does not allow to estimate the unique effect of a set of explanatory variables. However, variation partitioning or partial canonical analysis (Borcard et al., 1992) may help to estimate the fraction of the variance in diatom community distribution explained by different sets of environmental factors influencing. Multivariate data analyses were performed on the diatom dataset to explore the main gradients of floristic variation and to detect and visualize similarities in the diatom samples. Diatom data were analysed by means of detrended correspondence analysis (DCA) (Hill \& Gauch, 1980) to determine the length of the gradient. DCA revealed that the gradient was greater that 3 standard deviation units (4.3) in the regional study, therefore unimodal ordination techniques would be more appropriate. However, the gradient length was smaller than 3 standard deviation units (2.7) in the watershed study and linear ordination techniques should be applied (ter Braak and Ŝmilauer, 2002). Constrained ordination, canonical correspondence analysis (CCA) and Redundancy Analyses (RDA) were used to relate diatom assemblage structure to all predictor environmental variables and to explore the relationships among and between species and the environment (Ter Braak \& Verdonschot, 1995). According to this preliminary CCA and RDA, we identified collinear variables and selected a subset on inspection of variance inflation factors (VIF<20) (ter Braak \& Šmilauer, 2002. Forward). Explanatory variables were submitted to the step-wise forward selection and procedure in which the statistical significance of each variable was tested by the Monte Carlo permutation test (ter Braak \& Šmilauer, 2002),(999 permutations). Probabilities for multiple comparison were corrected using the Bonferroni correction. Then, partial CCA and RDA were used to separate and examine the relative importance for the species data of two sets of explanatory variables on the diatom assemblage 
(Borcard et al., 1992). We were interested in separating metal pollution from all the other

225

226

227

228

229

230

231

232

233

234

variables and then testing whether these two different groups were redundant to each other, or whether they each explained unique aspects of species composition. The variance partitioning was conducted in different steps: (1) CCA/RDA of the species matrix constrained by the environmental matrix; (2) CCA/RDA of the species matrix constrained by the metal pollution matrix; (3) partial CCA/RDA of the species matrix constrained by the environmental matrix and using the metal pollution matrix as covariables; (4) partial CCA/RDA of the species matrix constrained by the metal pollution matrix and using the environmental matrix as covariables. The data set included two sampling times (summer 2002 and spring 2003) in the regional study, and three sampling times (December 2003, February and July 2004) in the watershed study. The set of variables included are detailed in Tables 2, 4 and 5.

Only diatom taxa occurring in more than 2 samples with a relative proportion $\geq 1 \%$ were included in the analyses. Taxa abundance was square root transformed to reduce the effect of highly variable population densities on ordination scores. Environmental data (except $\mathrm{pH}$ ) were logarithmically transformed before analysis to reduce skewed distributions. All ordinations were performed using CANOCO version 4.5 (ter Braak \& Šmilauer, 2002).

\section{Results}

\subsection{Regional study}

Physical, chemical and biological characteristics. Streams were characterized by conductivities from 57 to $2750 \mu \mathrm{S} \mathrm{cm}^{-1}$ and a variety of nutrient levels (Table 2). Metal concentration ranged between $<0.1-0.8 \mu \mathrm{g} / \mathrm{L}$ for $\mathrm{Cd}$ and $\mathrm{Hg},<1-10 \mu \mathrm{g} / \mathrm{L}$ for $\mathrm{As}, \mathrm{Cr}$ and $\mathrm{Pb}$ and $<10-80 \mu \mathrm{g} / \mathrm{L}$ for $\mathrm{Cu}, \mathrm{Ni}$ and Zn. Comparing spring and summer data, average values of dissolved salts (conductivity and chloride), nutrients (mainly phosphate) and metal CCU were slightly higher in summer than in spring, but the variability between sites (see the standard error of the mean) was always much higher than temporal variability (Table 2). Over 288 taxa of diatoms were identified from the 
study sites. Of those, twenty-three diatom taxa were included (typically represented $>1 \%$ of the

250 diatom community at all sites).

251 Metal Cumulative Concentration Units categories. Heavy metal concentrations, expressed as

252 CCU do not differ greatly among stations and ranged from 0.065 to 6.383 (mean 1.906) (Table 2) and were less than 2.0 at the majority of sites $(68 \%)$. The relative importance of $\mathrm{As}, \mathrm{Cd}, \mathrm{Cr}$ and $\mathrm{Ni}$ was $<5 \%$ to the overall $\mathrm{CCU}$. Pb was the most important metal and accounted for $53 \%$ of all the CCU followed by $\mathrm{Cu}(24 \%), \mathrm{Hg}(12 \%)$ and $\mathrm{Zn}(8 \%)$. The relative contribution of each metal to the $\mathrm{CCU}$ differed among the three metal categories (Fig. 2). The contribution of $\mathrm{Cu}$ and $\mathrm{Zn}$ was c. $57 \%$ and $37 \%$ respectively at background sites. $\mathrm{Pb}$ was the most important metal at low and medium level sites (CCU > 1.0). The relative importance of $\mathrm{Cu}$ and $\mathrm{Zn}$ decreased at low and medium level sites, while $\mathrm{Hg}$ and $\mathrm{Pb}$ increased. $\mathrm{Zn}$ had the highest absolute concentration in the streams, but its contribution to the $\mathrm{CCU}$ was considerably smaller that that of $\mathrm{Cu}$ and $\mathrm{Pb}$ once the criterion values and the effects of water hardness on bioavailability were taken into account.

Relative importance of metal pollution vs. other environmental factors. The summary of the ordination gives an overall measurement of how much variation can be related to both explanatory variables. However, not all diatom species are equally well explained by the same set of environmental variables. The fit for species can be used as a measurement to find out which species are better represented and the percentage of variance fit by each set of explanatory variables.

The first run of the data analysis (i.e. environmental variables as explanatory variables) showed that organic pollution and conductivity were statistically significant. In the second run (i.e. metal pollution as explanatory variables) chromium and CCU turned out to be statistically significant. Environmental variables alone accounted for $22.6 \%$ of explained variation. The metal pollution represented $9.8 \%$ of explained variation. The results showed that $5.1 \%$ of the diatom data variation was shared by the environmental and metal pollution variables. Finally, the 
unexplained variation corresponded to $62.5 \%$.

The percentage of variance explained by metal pollution and other environmental factors with respect to the unconstrained variance differs among the different species (Table 3). Navicula saprohila has its distribution mostly explained by metal pollution (Fig 2). Gomphonema pumilum, Gomphonema parvulum, Nitzschia palea, Cymbella sinuata, Cymbella minuta, Nitzschia frustulum, Cyclotella meneghiniana, Achnanthes minutssima, Gomphonema minutm, Nitzschia amphibia, Navicula minima, and Cocconeis placentula were mostly related to the other environmental factors. Navicula seminulum and Navicula veneta had both large amounts of their distribution explained by the two sets of explanatory variables (Table 3 ).

\subsection{Watershed study}

Physical, chemical and biological characteristics. Based on the physical and chemical variables analyzed, two sampling sites had low nutrient concentration (B1 and T1), another two sites were slightly eutrophic due to diffuse pollution (B2 and $\mathrm{Ol}$ ), and the remaining two (T2 and Rd) had the highest nutrient concentration 3-10 times higher ammonia, phosphate and DOC (Table 4). There were no significant differences between sampling times (ANOVA, $p<0.001$ ) since the variability between sampling sites was always higher than temporal variability (Table 4).

Metal contents. The water metal concentration (Table 5) followed a similar pattern to nutrients and conductivity but differences between sites were less evident. Metal concentration was lower at B1, T1 and O1; and slightly higher at B2 and Rd; while metal levels in biofilms were lower at B1, $\mathrm{B} 2$ and $\mathrm{T} 1$, higher at $\mathrm{O} 1$ and $\mathrm{T} 2$ and reaching maximum at $\mathrm{Rd}$ (Table 5). The bioavailable metal portion in water - estimated with DGT analysis - followed the same pattern but amounted to 16 $23 \%$ of total dissolved metal content (average percentage Ni: $23,1 \%$; $\mathrm{Cu}: 23,2 \%$; $\mathrm{Zn}: 16,7 \%$; $\mathrm{Cd}$ : 15,6\%; and $\mathrm{Pb}: 19,6 \%$ respectively). A good correlation between water concentration and metal levels in biofilms was obtained for $\mathrm{Zn}(\mathrm{r}=0,86) ; \mathrm{Cu}, \mathrm{As}, \mathrm{Cd}$, and $\mathrm{Pb}$ concentrations in water were very low $(<5 \mathrm{ug} / \mathrm{L})$, close to the detection level of the method showing a high scatter and were not 
significantly correlated with biofilm metal concentration. (average 0.34). The relative importance of $\mathrm{As}, \mathrm{Hg}$ and $\mathrm{Ni}$ to the overall $\mathrm{CCUw}$ was $<10 \%$. Cd was the most important metal and accounted for $25 \%$ of all the CCUw followed by $\mathrm{Zn}$ and $\mathrm{Cu}$ (24 $\%)$ and $\mathrm{Pb}(17 \%)$. In order to increase sensitivity in the detection of changes due to metal pollution, biofilm metal concentration was used to calculate CCUb. CCUb values ranged between 0.90 and 15.4. The relative contribution of each metal to the CCUb was similar among the three metal categories (Fig. 3a). In this case the relative importance of $\mathrm{As}, \mathrm{Ni}, \mathrm{Zn}$ and $\mathrm{Cu}$ was $<10 \%$ to the overall CCUb. $\mathrm{Pb}$ was the most important metal and accounted for $68 \%$ of all the CCUb followed by Cd (18\%).

Diatom community responses to metal levels. Phosphate, nitrate and water temperature were the

310 environmental variables with a significant effect on the diatom distribution. These environmental 311 variables alone accounted for $23.2 \%$ of explained variation. Metal concentration and CCU units in

312 biofilm (Cu-biofilm, Pb-biofilm and CCU biofilm) turned out to be statistically significant 313 amongst the metal pollution variables. Metal pollution represented $21.1 \%$ of the explained 314 variation. Up to $15.9 \%$ of the diatom data variation was shared by the environmental and metal 315 pollution variables. Finally, the unexplained variation corresponded to $39.8 \%$. The percentage of variance explained by both sets of variables independently with respect

317 to the unconstrained variance differs among the different species. Navicula gregaria, Amphora 318 pediculus, Rhoiscosphenia abbreviate, Navicula tripunctata, Nitzschia fonticola, Navicula

319 subhamulata and Navicula cryptotenella had their distribution mostly explained by metal 320 pollution (Table 6). In fact, the RDA first axis scores differ between CCU metal levels (ANOVA; $\mathrm{p}=0.059 ; \mathrm{F}=3.469)$. Overall, this group of species is absent or present with low abundance at the lowest metal category, increase with metal content, and rise up to more $30 \%$ of total abundance in

323 the highest metal category (Fig. 3 b, c, d, e and f).. The most significant case is Navicula gregaria. 
324 In this case, metal pollution explains $42 \%$ of variance. This taxon is absent at sites with low metal

325 content in biofilms, and increases with increasing metal content (Fig 3b) presenting significant

326 differences in the abundance between CCU metal categories (ANOVA; $\mathrm{p}=0.03 ; \mathrm{F}=8.93$ ).

327 Gomphonema minutum, Gomphonema parvulum, Cocconeis pediculus were amongst the most

328 related to other environmental factors. Finally, Nitzschia frustulum, Cymbella minuta, Achnanthes

329 minutissima, Melosira varians, Navicula menisculus var. grunowii, Gomphonema micropus,

330 Cocconeis placentula, Navicula capitatoradiata and Nitzschia dissipata were both explained by

331 metal pollution and other environmental factors (Table 6). 


\section{Discussion}

333 Based on the opportunity to evaluate the response of numerous species simultaneously,

334 community ecotoxicology can provide a much broader context for the assessment of environmental contamination than the study of individual species (Clements and Newman, 2002).

Different species in a community respond differentially to contaminants and other stressors because of differences in life history characteristics and tolerance. Thus, the composition of communities at different locations, or at different points in time, provide useful information about the environmental conditions.

Diatom communities are used in this study as indicators of different types of pollution: eutrophication and organic pollution vs. metal pollution. The relative contribution of each type of

342 pollution and the respective key environmental variables differ between the two case-studies.

343 Focusing on the first type of pollution (eutrophication and organic pollution), the percentage of 344 variance explained was similar between both cases (22.6\% and $23.2 \%$, respectively), but the key environmental variables were different: organic pollution and conductivity in the regional study and nutrients (nitrate and phosphate) and water temperature in the Fluvià watershed. Many studies

347 show that key environmental variables which are important determinants of freshwater

348 communities function and structure are influenced by factors operating at different temporal and spatial scales. The regional study included sites of different order from different watersheds covering a broad range of conditions at the highest spatial level. Diatoms followed a gradient of pollution but also differed in the growing conditions for total dissolved salts $(57-2750 \mu \mathrm{S} / \mathrm{cm})$.

352 Environmental factors explaining diatom assemblage distribution at a large spatial scale have been clearly shown to be predominantly related to physiographic characteristics (Leira \& Sabater, 2005) and water mineralization (Potapova \& Charles, 2003). in order to provide the minimum physiographical and geochemical variability. All sampling sites 
had similar hydromorphology (2-3 order streams) draining the same geological area. In this case diatoms followed a clear eutrophication gradient. Repetitive sampling over time (2-3 times) provided temporal variability which was also influencing diatom species due to seasonal water temperature changes.

Focusing on the second type of pollution analyzed, i.e. metal pollution, the percentage of variance explained in the regional study was lower $(<10 \%)$ than in the Fluvià watershed $(21.1 \%)$. This difference was mainly due to the variables included in the analysis: water metal concentration in the first case and both, water and biofilm metal concentrations in the second one. As it was expected, water metal content was a better predictor of the diatom community structure in the regional than in the watershed study. Taking the CCU as a summary of water metal pollution, all sampling points included in the Fluvià case-study correspond to the lower metal category of the regional data set. In addition, while metal loads exceeded expected toxicity thresholds in some of the cases included in the regional study we did not expect metal toxicity in the watershed study. The Fluvià case-study is a clear example of low-metal pollution from diffuse (B2 and $\mathrm{Ol}$ ) and point sources (the outflow of relatively small WWTP in T2 and Rd). In spite of the fact that metal loads were relatively high, the percentage of variance explained by metal pollution in the water phase in the regional case was low, and the partition of variance included only the most polluted cases. It was related with only one diatom species: Navicula saprophila, considered to be very tolerant to pollution (Soininen 2002, Rakowska 2004, Tornés et al. 2007). Navicula saprophila was a dominant taxon (>60\% relative abundance) during spring in the lower part of the Besós (J034 and J048) and Francolí rivers (J079). One of the sites (J048) is located in an industrial area and has the highest metal loads which exceed quality thresholds $(0.80 \mu \mathrm{g} / \mathrm{L} \mathrm{Cd}$, $4 \mu \mathrm{g} / \mathrm{L} \mathrm{Hg}$ and 6.26 CCU). Water metal concentration was also above the quality threshold at $380 \mathrm{~J} 048$ (3.58 CCU), but relatively low at J034 (0.29 CCU). Differences in TOC were very broad and may have modulated periphyton metal bioavailability. Furthermore, it has been reported that $\mathrm{Cu}$ and $\mathrm{Zn}$ toxicity on periphyton are influenced by nutrient loads (Ivorra et al., 2002; Guasch et al., 
2004, Paulsson et al., 2000). Differences in phosphate and nitrate concentration may also influence the sensitivity of periphyton modulating the response of diatoms to metal under different nutrient conditions.

Total metal concentration in the water has been considered a poor indicator of metal availability (Campbell, 1995; Tusseau et al., 2007). Metal loads are derived from single water samples which only record a limited time period. Point water sampling cannot account for the temporal variability and detecting the occurrence of higher concentration episodes that may have been recorded either with passive samplers (integrating up to the 7 previous days) or benthic biota (fluvial biofilms may integrate several weeks of exposure). Furthermore, it is well known that biologically active surfaces (periphyton and sediments) play an important role in reducing water column concentrations following effluent release via adsorption and complexation processes (Bubb \& Lester, 1995) providing an integrated representation of the accumulation of toxicants in the benthic environment (Meylan et al., 2004). In our study, metal content in biofilms accounted for a significant portion of diatom species variance. The partial RDA identifies seven diatom species related with biofilm metal concentration. Three different patterns were observed. Two species, (Navicula gregaria and Rhoicosphenia abbreviata) which were not found in the reference sites, increased linearly with biofilm metal concentration. In the case of Navicula gregaria, the relative abundance increased from 0 to $12 \%$. In the context of our area of study, this species may be considered indicative of slight metal concentration increase. In agreement with our results, $N$. gregaria was considered to be tolerant to metal pollution by Chanson et al. (2005) but also to organic pollution (Gomà et al., 2005). Another diatom species (Nizschia tripunctata), already present in the reference sites, showed a slight increase at higher metal concentration. Finally, Nitzschia fonticola and Navicula cryptotenella showed a non-linear increase with metal concentration. Overall, this group of species increased from $<5 \%$ to more than $30 \%$ of the total abundance with increasing metal concentration (Fig. 3). Rogers et al. (2002) also found a good correlation between metal concentration in vegetative habitats and the corresponding biological 
condition using macroinvertebrate communities. The percentage of variance explained by metal concentration in vegetative habitats was $22 \%$, very close to the $23 \%$ variance explained by metal concentration in the biofilms of our investigation.

Behra et al. (2002) indicate that metal concentration in biofilms is influenced by metal

413 speciation and may be subject to temporal dynamics in the environment. The used DGT technique

414 is believed to give an estimation of the labile metal fraction in the water. The average percentage

415 of DGT labile metals of the total dissolved metal concentrations in this study were in good

416 agreement with results obtained by Odzak et al. (2002), revealing that only a minor fraction of the

417 total dissolved metal content is bioavailable.

The consistency between temporal replicates, and the results obtained by passive samplers indicate that biofilm metal concentration can be used to evaluate aquatic metal contamination and bioavailability. Furthermore, since water metal concentration was near detection limits in some reference sites, the higher metal contents measured in biofilms allowed a better characterization of metal pollution. This measurement provided a higher sensitivity for the elements such as As or Cd that occurred at very low concentration in the aqueous phase.

The results obtained in the Fluvia watershed indicate that the biofilm metal analysis may have improved the assessment of metal pollution effects at a broader scale.

Looking for generalizations, large scale studies are a tempting approach for research and also management purposes. However, they are influenced by regional scale variability that may conceal the effects of human impacts. Conversely, human impacts are better detected in small scale studies, including reference and impacted situations, within a restricted range of environmental variability. However, any conclusion drawn from these studies is restricted to the

431 area of study and cannot be easily generalized. Surprisingly, few studies have addressed the 432 importance of scale. The comparison between the two case studies here illustrates the relevance of 433 the scale but also the importance of using a good set of explanatory variables. In addition, the 
results obtained in our local case study, the Fluvià watershed, reveal that diatom assemblages may

435

436

437 respond to low levels of metal pollution. Given the regional differences in climate and land use we were not surprised to find differences in community composition at the regional scale that were correlated with these strong ecological gradients, although the finding that at watershed level streams were responding to low metal pollution was of interest. This finding was possible by means of a good sampling strategy, but also thanks to the use of highly sensitive analytical techniques for the study of metal concentration and bioavailability. Analyses of metal traces in the water phase and the biota (fluvial biofilms), together with the use of passive samplers are recommended for assessing low metal pollution.

\section{Conclusions}

The results obtained illustrate two key points in field sampling: the scale of study and the importance of choosing a good set of explanatory variables. Large-scale studies of human-derived impacts are complicated by the natural variability between sites, requiring the inclusion of many variables accounting for all sources of variation occurring at different scales (physiographical, geochemical and biological). This difficulty can partially be solved if human-impact is analyzed at a smaller scale, including contrasted reference and impacted sites. Focusing on metal pollution, metal water concentration is a poor indicator of metal availability in chronic low metal pollution scenarios. Analyses of metal traces in the water phase and the biota (fluvial biofilms) together with the use of passive samplers are, therefore, recommended.

In addtion, the cases presented in this paper show the usefulness of variance partitioning analysis to evaluate the relative contribution of different sources of pollution to the ecological status of fluvial systems when they occur simultaneously, i.e. low metal pollution, eutrophication and organic pollution. Application of these techniques allow to assess changes in the composition of diatom communities at different locations, or at different points in time, in response to overlapping environmental condition gradients, including situations of low metal pollution. 


\section{Acknowledgments}

461 The "Serveis Científics i Tècnics" at the University of Girona provided its facilities and technical 462 help for ICP-MS metal analysis. The research was funded by the Spanish-French exchange 463 program "Picasso" (HF-2002-0065); the Spanish Ministry Science and Education 464 (FLUVIALFITOMARC CGL2006-12785), and the EC Sixth Framework Program (MODELKEY 465 511237-2 GOCE and KEYBIOEFFECTS MRTN-CT-2006-035695). Elisabeth Tornés and 466 Alexandra Serra benefit from a grant of the local authorities "beca Ciutat d'Olot". The Agència 467 Catalana de l'Aigua provided all data used for the regional study-case. 
470 ACA, 2003. Viability analysis and proposal of phytobenthonic indicators for the water quality in

471 Catalan fluvial systems (Anàlisi de la viabilitat i proposta d'indicadors fitobentònics de la qualitat 472 de l'aigua per als cursos fluvials de Catalunya). Report of the Agència Catalana de l'Aigua, 473 Barcelona.

474

American Public Health Association APHA, 1989. Standard Methods for the Examination of

Water and Wastewater. American Public Health Association, Washington, DC, P. 1220.

Behra, R., R. Landwehrjohann, K. Vogel, B. Wagner \& L. Sigg, 2002. Copper and Zinc content of periphyton from two rivers as a function of dissolved metal concentration. Aquatic Sciences

480 64: 300-306.

481

482

Blank, H., W. Admiraal, R. F. M. J. Cleven, H. Guasch, M. A. G. T. van den Hoop, N. Ivorra, B.

Nyström, M. Paulsson, R. P. Petterson, S.Sabater \& G. M. J. Tubbing, 2003. Variability in zinc tolerance, measured as incorporation of radio-labeled carbon dioxide and thymidine, in periphyton communities sampled from 15 European river stretches. Arch. Environ. Contam. Toxicol. 44 :1729.

Boisson, J. C. \& Y. Perrodin. 2006. Effects of road runoff on biomass and metabolic activity of periphyton in experimental streams. Journal of Hazardous Materials A132: 148-154

490 
493

494 Bubb, J. M. \& J. N. Lester, 1995. Factors controlling the accumulation of metals within fluvial systems. Environmental Monitoring \& Assessment 41: 87-105.

496

497 Campbell, P. G. C., 1995. Interaction between trace metals and aquatic organisms: a critique of 498 the free-ion activity model. In: Tessier, A. \& D. R. Turner (eds.), Metal speciation and 499 bioavailability in aquatic systems. John Wiley and sons, Chichester: 45-97.

501 CEN. European Committee for Standardization, 2000. Water quality. Guidance standard for the routine sampling and pre-treatment of benthic diatoms from rivers for water quality assessment. European Standard. prEN 13946.

CEN. European Committee for Standardization, 2001. Water quality. Guidance standard for the identification and enumeration of benthic diatom samples from rivers and their interpretation. European Standard. TC 230 WI 00230164.

509 Chanson, F., A. Cordonier, P. Nirel, 2005. Essai de mise au point d'un indice diatomique pour 510 évaluer la pollution métallique des cours d'eau du Genevois (Genève, Suisse) 24ème Colloque de 511 l'Association des Diatomistes de Langue Française, Bordeaux, France 6-8 septembre 2005, p 37.

513 Clements, W. H., D. M. Carlisle, J. M. Lazorchak \& P. C. Johnson, 2000. Heavy metals structure

514 benthic communities in Colorado mountain streams. Ecological Applications 10: 626-638.

516 Clements, W. H. \& M. C. Newman, 2002. Community Ecotoxicology, Hierarchical

517 Ecotoxicology Series, Newman, M.C., (ed), Wiley and Sons, 336 pp. 
519 Davison, W., G. Fones, M. Harper, P. Teasdale \& H. Zhang, 2000. Dialysis, DET and DGR: in

520 situ diffusional techniques for studying water, sediments and soils. In Buffle, J. \& G. Horvai (eds),

521 In situ monitoring of Aquatic Systems; Chemical analysis and speciation. Wiley, Chichister.

522

523 Davison, W. \& H. Zhang, 1994. In situ speciation measurements of trace components in natural 524 waters using thin-film gels. Nature 376: 546-548.

525

526 Gomà, J., F. Rimet, J. Cambra, L. Hoffmann \& L. Ector, 2005. Diatom communities and water

527 quality assessment in Mountain Rivers of the upper Segre basin (La Cerdanya, Oriental Pyrenees).

528 Hydrobiologia 551: 209-225.

529

530 Gold, C., A. Feurtet-Mazel, M. Coste \& A. Boudou, 2003. Effects of cadmium stress on 531 periphytic diatom communities in indoor artificial streams. Freshwater Biology 48, 316-328.

532

533 Guasch, H., M. Paulsson \& S. Sabater, 2002. Effect of copper on algal communities from 534 oligotrophic calcareous streams. Journal of Phycology 38, 241-248.

536 Guasch, H., E. Navarro, A. Serra \& S. Sabater, 2004. Phosphate limitation influences the 537 sensitivity to copper in periphytic algae. Freshwater Biology 49: 463-473.

538

539 Hickey, C.W. \& L. A. Golding, 2002. Response of macroinvertebrates to copper and zinc in a 540 stream mesocosm. Environmental Toxicology \& Chemistry 21(9), 1854-1863.

542 Hill, M.O. \& H. E. J. Gauch, 1980. Detrended correspondence analysis: an improved ordination 
technique. Vegetatio 42: 47-58.

544

545 Hirst, H., I. Jüttner \& S. J. Ormerod, 2002. Comparing the responses of diatoms and

546 macroinvertebrates to metals in upland streams of Wales and Cornwall. Freshwater Biology 47:

$547 \quad 1752-1765$.

548

549

Ivorra, N., J. Hettelaar, G. M. J. Tubbing, M. H. S. Kraak, S. Sabater \& W. Admiraal, 1999.

550

Translocation of microbenthic algal assemblages used for "in situ" analysis of metal pollution in rivers. Archives of Environmental Contamination \& Toxicology 37: 19-28.

552

553

Ivorra, N., J. Hettelaar, M. H. S. Kraak, S. Sabater \& W. Admiraal, 2002. Responses of biofilms 554 to combined nutrient and metal exposure. Environmental Toxicology \& Chemistry 21(3): 626632.

556

557

Jüttner, I., S. Sharma, B. M. Dahal, S. J. Ormerod, P. J. Chimonides \& E. J. Cox, 2003. Diatoms as indicators of stream quality in the Kathmandu Valley and Middle Hills of Nepal and India. Freshwater Biology 48: 2065-2084.

560

Kelly, M.G., A. Cazaubon, E. Coring, A. Dell'uomo, L. Ector, B. Goldsmith B., H. Guasch, J.

Hürlimann, A. Jarlman, B. Kawecka, J. Kwandrans, R. Laugaste, A. Lindstrom, M. Leitao, P.

Marvan, J. Padisak, E. Pipp, J. Prygiel, E. Rott, S. Sabater, H. Van Dam \& J. Vizinet, 1998.

Recommendations for the routine sampling of diatoms for water quality assessments in Europe.

Journal of Applied Phycology 10: 215-224.

567 Krammer, K. \& H. Lange-Bertalot, 1991-1997. Bacillariophyceae, 2 (1-4). In Ettl, H., J. Gerloff,

H. Heynig \& D. Mollenhauer (eds) Süsswasserflora von Mitteleuropa. Fischer, Stuttgart. 
570 Lange-Bertalot, H., 2001. Navicula sensu stricto, 10 genera separated from Navicula sensu lato,

571 Frustulia. In Lange-Bertalot, H. (ed), Diatoms of Europe. Gantner Verlag, Ruggell, pp. 526.

572

573 Leira, M. \& S. Sabater, 2005. Diatom assemblages distribution in catalan rivers, NE Spain, in

574 relation to chemical and physiographical factors. Water Research 39: 73-82.

575

576 Meylan S., R. Behra \& L. Sigg, 2003. Accumulation of $\mathrm{Cu}$ and $\mathrm{Zn}$ in periphyton in response to 577 dynamic variations of metal speciation in freshwater. Environmental Science \& Technology 37:

$578 \quad 5204-5212$.

579

580 Meylan S., R. Behra \& L. Sigg, 2004. Influence of metal speciation in natural freshwater on 581 bioaccumulation of copper and zinc in periphyton: a microcosm study. Environmental Science \& 582 Technology 38: 3104-3111.

583

584 Nunes, M. L., E. Ferreira da Silda \& S. F. P. de Almeida, 2003. Assessment of water quality in the 585 Caima and Mau river Basins (Portugal) using geochemical and biological indices. Water, Air, and 586 Soil Pollution 149: 227-250.

587

588 Odzak, N., D. Kistler, H. Xue \& L. Sigg, 2002. In situ trace metal speciation in a eutrophic lake using the technique of diffusion gradients in thin films (DGT). Aquatic Sciences 64: 292-299.

590

591 Paulsson, M., B. Nyström \& H. Blanck, 2000. Long-term toxicity of zinc to bacteria and algae in

592 periphyton communities from the river Göta Älv, based on a microcosm study. Aquatic

593 Toxicology 47: 243-257. 
Potapova, M. \& D. F. Charles, 2003. Distribution of benthic diatoms in US rivers in relation to conductivity and ionic composition. Freshwater Biology 48: 1311-1328.

Prygiel. J., P. Carpentier, D. Almeida, M. Coste, J. C. Druart, L. Ector, D. Guillard, M. A. Honore,

599 R. Iserentant, P. Ledeganck, C. Lalanne-Cassou, C. Lesniak, I. Mercier, P. Moncaut, M. Nazart,

600 N. Nouchet, F. Peres, V. Peeters, F. Rimet, A. Rumeau, S. Sabater, F. Straub, M. Torrisi, M.

601 Tudesque, B. Van de Vijver, H. Vidal, I. Vizinet \& N. Sidec, 2002. Determination of the

602 biological diatom index (IBD NF T 90-354): results of an intercomparison exercise. Journal of

603 Applied Phycology 14: 27-39.

604

605

Rakowska, B., 2004. Benthic diatoms in polluted river sections of central Poland. Oceanological

606 Hydrobiological Studies 33: 11-21.

607

608

609

Rogers, C. E., D. J. Barbander, M. T. Barbour \& H. F. Hemond, 2002. Use of physical, chemical, and biological indices to assess impacts of contaminants and physical habitat alteration in urban streams. Environmental Toxicology \& Chemistry 21(6): 1156-1167.

611

612 Soininen, J., 2002. Responses of ephilithic diatom communities to environmental gradients in 613 some Finnish rivers. International Revue Hydrobiologie. 87: 11-24.

614

615 ter Braak, C. J. F. \& P. F. M. Verdonschot, 1995. Canonical correspondence analysisanálisis and 616 related multivariate methods in aquatic ecology. Aquatic Sciences 37: 130-137.

617

618 ter Braak, C. J. F. \& P. Smilauer, 2002. CANOCO Reference Manual and CanoDraw for

619 Windows User's Guide: Software for Canonical Community Ordination, Version 4.5.

620 Microcomputer Power, Ithaca, NY, 500 pp. 
622 Tornés, E., J. Cambra, J. Gomà, M. Leira, R. Ortiz \& S. Sabater, 2007. Indicator taxa of benthic 623 diatom communities: a case study in Mediterranean streams. Ann. Limnol.-Int. J. Lim. 43: 1-11. 624

625 Torrisi, M., M. Tudesque, B. Van de Vijver, H. Vidal, I. Vizinet \& N. Sidec, 2002. Determination 626 of the biological diatom index (IBD NF T 90-354): results o fan intercomparison exercise. Journal 627 of Applied Phycology 12: 113-124.

628

629 Tusseau-Vuillemin, M. - H., C. Gourlay, C. Lorgeoux, J. - M. Mouchel, R. Buzier, R. Gilbin, J. 630 L. Seidel \& F. Elzab-Poulichet, 2007. Dissolved and bioavailable contaminants in the Seine river 631 basin. Science of the Total Environment 375: 244-256.

632

633 Zhang H., W. Davison, S. Miller \& W. Tych, 1995. In situ resolution measurements of fluxes of $634 \mathrm{Ni}, \mathrm{Cu}, \mathrm{Fe}$, and $\mathrm{Mn}$ and concentration of $\mathrm{Zn}$ and $\mathrm{Cd}$ in porewaters by DGT. Geochem. Cosmocim. 635 Ac. 59: 4181-4192.

636 
637

\begin{tabular}{|l|l|c|c|c|l|}
\hline River & Tributary & Code & Utm_x & Utm_y & type of pollution \\
\hline Ebre & $\begin{array}{l}\text { Noguera } \\
\text { Pallaresa }\end{array}$ & J164 & 346200 & 4697150 & Reference site \\
\hline Francolí & main course & J079 & 351880 & 4557749 & Industrial and agricultural \\
\hline Llobregat & main course & J117 & 414345 & 4676946 & Reference site \\
\hline & main course & J084 & 409900 & 4595207 & Urban, industrial and agricultural \\
\hline & main course & J046 & 426317 & 4575155 & Urban, industrial and agricultural \\
\hline Besòs & main course & J043 & 432745 & 4593970 & Industrial, urban and agricultural \\
\hline & main course & J048 & 433470 & 4589092 & Industrial, urban and agricultural \\
\hline & main course & J069 & 436397 & 4599652 & Industrial, urban and agricultural \\
\hline Tordera & main course & J083 & 458991 & 4615836 & Agricultural \\
\hline & main course & J062 & 474623 & 4621201 & Urban \\
\hline & Vallfogona & J124 & 457436 & 4614528 & Agricultural \\
\hline & Arbúcies & J066 & 468683 & 4620831 & Urban and industrial \\
\hline Ter & main course & Te0 & 438961 & 4697736 & Reference site \\
\hline & main course & J034 & 440624 & 4648776 & Agricultural \\
\hline & main course & J060 & 467193 & 4648385 & Agricultural \\
\hline & Onyar & J020 & 486931 & 4646082 & Agricultural \\
\hline Fluvià & main course & J013 & 459669 & 4671043 & Agricultural \\
\hline & Bianya & J070 & 459601 & 4673988 & Agricultural \\
\hline & Turonell & J104 & 462182 & 4673130 & Urban, agricultural and industrial \\
\hline & Ridaura & J105 & 457655 & 4674088 & Urban, agricultural and industrial \\
\hline Muga & Muga & J012 & 488502 & 4687167 & Agricultural \\
\hline
\end{tabular}

640 Table 1. Summary of the location (river basin, tributary, ACA code and UTM coordinates) and 641 main type of pollution (in order of importance) of the cases selected in the regional study. 


\begin{tabular}{|l|r|r|r|r|r|r|r|}
\hline & \multicolumn{2}{|c|}{ Summer } & \multicolumn{2}{|c|}{ Spring } & \multirow{2}{*}{ Min. } & Max. & $\begin{array}{l}\text { Tox. } \\
\text { threshold }\end{array}$ \\
\hline & Mean & s.e. & Mean & \multicolumn{1}{|c|}{ s.e. } & & & \\
\hline pH & 7.57 & 0.12 & 7.95 & 0.10 & 6.7 & 8.5 & \\
\hline Conductivity $(\mu \mathrm{S} / \mathrm{cm})$ & 1142 & 203.8 & 853.6 & 196.3 & 57.0 & 2750.0 & \\
\hline Temperature $\left({ }^{\circ} \mathrm{C}\right)$ & 20.49 & 0.77 & 17.28 & 1.53 & 8.0 & 25.0 & \\
\hline Dissolved oxygen $(\mathrm{mg} / \mathrm{L})$ & 7.42 & 0.75 & 14.96 & 5.98 & 4.0 & 74.6 & \\
\hline Nitrate $(\mathrm{mg} / \mathrm{L})$ & 11.11 & 1.83 & 10.99 & 2.01 & 0.4 & 22.3 & \\
\hline Phosphate $(\mathrm{mg} / \mathrm{L})$ & 2.40 & 0.87 & 0.62 & 0.18 & 0.1 & 12.3 & \\
\hline Sulphate $(\mathrm{mg} / \mathrm{L})$ & 113.6 & 27.27 & 118.9 & 29.38 & 4.0 & 384.8 & \\
\hline Chloride $(\mathrm{mg} / \mathrm{L})$ & 299.7 & 140.5 & 126.2 & 37.38 & 2.4 & 2041.0 & \\
\hline Bicarbonate $(\mathrm{mg} / \mathrm{L})$ & 265.6 & 30.6 & 253.0 & 36.26 & 35.0 & 417.4 & \\
\hline Ammonium $(\mathrm{mg} / \mathrm{L})$ & 3.73 & 1.72 & 4.02 & 2.01 & 0.1 & 20.9 & \\
\hline Potassium $(\mathrm{mg} / \mathrm{L})$ & 18.24 & 9.72 & 9.23 & 2.69 & 0.1 & 141.7 & \\
\hline Calcium $(\mathrm{mg} / \mathrm{L})$ & 93.23 & 13.14 & 98.81 & 14.46 & 11.6 & 220.3 & \\
\hline Magnesium $(\mathrm{mg} / \mathrm{L})$ & 19.83 & 6.24 & 22.14 & 5.04 & 1.0 & 98.0 & \\
\hline Sodium $(\mathrm{mg} / \mathrm{L})$ & 179.6 & 72.97 & 93.11 & 29.46 & 1.4 & 1045.3 & \\
\hline TOC $(\mathrm{mg} / \mathrm{L})$ & 5.27 & 1.37 & 5.05 & 1.05 & 0.5 & 16.5 & \\
\hline Cd $(\mu \mathrm{g} / \mathrm{L})$ & $<0.1$ & & 0.07 & 0.07 & $<0.1$ & 0.8 & 0.25 \\
\hline Cr $(\mu \mathrm{g} / \mathrm{L})$ & $<0.1$ & & 0.93 & 0.66 & $<0.1$ & 6.60 & 74 \\
\hline Cu $(\mu \mathrm{g} / \mathrm{L})$ & 9.40 & 3.34 & 5.03 & 1.42 & $<5$ & 50.0 & 9 \\
\hline Pb $(\mu \mathrm{g} / \mathrm{L})$ & 1.07 & 0.77 & $<1$ & & $<1$ & 10.0 & 2.5 \\
\hline Ni $(\mu \mathrm{g} / \mathrm{L})$ & 14.64 & 6.51 & 8.20 & 4.44 & $<1$ & 80.0 & 52 \\
\hline Zn $(\mu \mathrm{g} / \mathrm{L})$ & 37.45 & 4.75 & 35.11 & 4.37 & 6 & 63.0 & 120 \\
\hline As $(\mu \mathrm{g} / \mathrm{L})$ & $<1$ & & 2.31 & 1.21 & $<1$ & 10.0 & 150 \\
\hline Hg $(\mu \mathrm{g} / \mathrm{L})$ & 0.04 & 0.04 & 0.36 & 0.36 & $<0.1$ & 4.00 & 0.77 \\
\hline CCU & 3.56 & 0.67 & 3.30 & 0.92 & 0.065 & 6.383 & \\
\hline & & & & & & & \\
\hline
\end{tabular}

645

646

647

648

649 Table 2. Physico-chemical variables used in the CCA of the regional study (Catalonia, NE Spain).

650 Average and standard error of summer $(n=14)$ and spring $(n=11)$ data, minimum (Min.);

651 Maximum (Max.) values recorded $(\mathrm{n}=25)$ and corresponding toxicity threshold.

652 


\begin{tabular}{|l|l|c|c|c|c|}
\hline \multirow{2}{*}{ Code } & Taxon & \multicolumn{2}{|c|}{$\begin{array}{c}\text { Fraction of total } \\
\text { variance }\end{array}$} & \multicolumn{2}{c|}{$\begin{array}{c}\text { Fraction of } \\
\text { explained variance }\end{array}$} \\
\hline & & Environ. & metals & Environ. & Metals \\
\hline NVEN & Navicula veneta Kützing & $\mathbf{6 1 . 2 1}$ & $\mathbf{1 9 . 7 6}$ & 75.6 & 24.4 \\
\hline \multirow{2}{*}{ GPUM } & $\begin{array}{l}\text { Gomphonema pumilum (Grunow) } \\
\text { Reichardt \& Lange-Bertalot }\end{array}$ & $\mathbf{5 2 . 9 0}$ & 4.07 & 92.9 & 7.1 \\
\hline GPAR & Gomphonema parvulum Kützing & $\mathbf{5 2 . 7 2}$ & 7.8 & 87.1 & 12.9 \\
\hline NPAL & Nitzschia palea (Kütz) Smith & $\mathbf{4 7 . 8 6}$ & 10.89 & 81.5 & 18.5 \\
\hline CSIN & Cymbella sinuata Gregory & $\mathbf{4 5 . 6 3}$ & 2.73 & 94.4 & 5.6 \\
\hline CMIN & Cymbella minuta Hilse ex Rabenhorst & $\mathbf{4 3 . 2 4}$ & 0.93 & 97.9 & 2.1 \\
\hline NIFR & Nitzschia frustulum (Kütingow) Grun. & $\mathbf{4 1 . 2 6}$ & 4.97 & 89.2 & 10.8 \\
\hline CMEN & Cyclotella meneghiniana Kützing & $\mathbf{3 3 . 4 4}$ & 3.62 & 90.2 & 9.8 \\
\hline AMIN & Achnanthes minutissima Kützing & $\mathbf{3 1 . 8 2}$ & 3.46 & 90.2 & 9.8 \\
\hline GMIN & Gomphonema minutum (Ag.) Agardh & $\mathbf{2 9 . 6 3}$ & 2.66 & 91.8 & 8.2 \\
\hline NAMP & Nitzscia amphibia Grunow & $\mathbf{2 8 . 1 0}$ & 1.19 & 95.9 & 4.1 \\
\hline NMIN & Navicula minima Grunow & $\mathbf{2 7 . 5 2}$ & 5.82 & 82.5 & 17.5 \\
\hline CPLA & Cocconeis placentula Ehrenberg & $\mathbf{2 6 . 4 1}$ & 0.58 & 97.9 & 2.1 \\
\hline NSEM & Navicula seminulum Grunow & $\mathbf{2 5 . 2 9}$ & $\mathbf{1 4 . 7 2}$ & 63.2 & 36.8 \\
\hline \multirow{2}{*}{ NSAP } & Navicula saprophila Lange-Bertalot \& & & & & \\
& Bonik & 1.22 & $\mathbf{4 7 . 1 2}$ & 2.5 & 97.5 \\
\hline
\end{tabular}

654

655

656

657

658 Table 3. Regional study. Results of the partial canonical correspondence analysis (CCA) with

659 forward selection of environmental variables.

660

661

662

663 


\begin{tabular}{|l|c|c|c|c|c|c|c|c|}
\hline site & Cond & phosphate & Nitrate & Ammonium & DOC & Oxygen & $\mathrm{pH}$ & Temp \\
$(\mu \mathrm{S} / \mathrm{cm})$ & $(\mu \mathrm{M})$ & $(\mu \mathrm{M})$ & $(\mu \mathrm{M})$ & $(\mathrm{mg} / \mathrm{L})$ & $(\mathrm{mg} / \mathrm{L})$ & & $\left({ }^{\circ} \mathrm{C}\right)$ \\
\hline B1 & 533 & 0.860 & 49.4 & 0.781 & 1.129 & 10.77 & 7.80 & 9.97 \\
& \pm 25 & \pm 0.912 & \pm 8.6 & \pm 0.487 & & \pm 1.01 & \pm 0.39 & \pm 7.11 \\
\hline T1 & 587 & 0.272 & 78.9 & 0.495 & 0.610 & 10.68 & 7.93 & 10.03 \\
& \pm 18 & \pm 0.156 & \pm 63.8 & \pm 0.008 & & \pm 1.30 & \pm 0.33 & \pm 6.41 \\
\hline B2 & 658 & 0.283 & 97.6 & 0.497 & 0.957 & 11.27 & 7.73 & 11.57 \\
& \pm 90 & \pm 0.250 & \pm 32.5 & \pm 0.006 & & \pm 0.96 & \pm 0.20 & \pm 5.95 \\
\hline O1 & 597 & 0.564 & 104.0 & 1.862 & 1.301 & 12.43 & 8.24 & 11.97 \\
& \pm 20 & \pm 0.534 & \pm 71.5 & \pm 1.825 & & \pm 0.79 & \pm 0.23 & 6.97 \\
\hline T2 & 1457 & 115.9 & 205.0 & 15.22 & 0.990 & 10.42 & 8.25 & 12.95 \\
\hline Rd & 1687 & 21.29 & 38.7 & 4.709 & 8.557 & 11.17 & 8.30 & 16.77 \\
& \pm 219 & \pm 3.309 & \pm 53.8 & \pm 1.318 & & \pm 4.12 & \pm 0.19 & \pm 5.83 \\
\hline
\end{tabular}

677 Table 4. Physico-chemical variables used in the RDA of the watershed study (Fluvià river).

678 Average and standard deviation for the three different sampling periods (December, February and 679 July) of conductivity (Cond), nutrient concentration, dissolved organic carbon (DOC), oxygen 680 concentration, $\mathrm{pH}$ and temperature at the different sampling sites $(\mathrm{n}=17)$.

681

682 


\begin{tabular}{|c|c|c|c|c|c|c|c|c|c|}
\hline & & B1 & T1 & B2 & $\mathrm{OL}$ & $\mathrm{T} 2 *$ & RD & Avg & \pm s.e. \\
\hline \multirow[t]{3}{*}{$\mathrm{Ni}$} & Biofilm & $\begin{array}{c}4.11 \\
\pm 0.01\end{array}$ & $\begin{array}{c}15.30 \\
\pm 17.71\end{array}$ & $\begin{array}{c}12.51 \\
\pm 14.63\end{array}$ & $\begin{array}{c}2.08 \\
\pm 1.20\end{array}$ & 4.20 & $\begin{array}{c}9.77 \\
\pm 3.62\end{array}$ & 8.00 & \pm 2.17 \\
\hline & water & $\begin{array}{c}19.54 \\
\pm 26.17\end{array}$ & $\begin{array}{c}3.12 \\
\pm 2.44\end{array}$ & $\begin{array}{c}1.18 \\
\pm 0.32\end{array}$ & $\begin{array}{c}3.03 \\
\pm 2.50\end{array}$ & 1.71 & $\begin{array}{c}6.02 \\
\pm 0.84\end{array}$ & 5.77 & \pm 2.84 \\
\hline & DGT & 0.21 & 0.13 & 0.22 & 0.35 & 0.40 & 3.40 & 0.78 & \pm 1.28 \\
\hline \multirow[t]{3}{*}{$\mathrm{Cu}$} & biofilm & $\begin{array}{c}1.93 \\
\pm 0.47\end{array}$ & $\begin{array}{c}0.85 \\
\pm 0.27\end{array}$ & $\begin{array}{c}1.03 \\
\pm 0.60\end{array}$ & $\begin{array}{c}1.26 \\
\pm 0.97\end{array}$ & 3.35 & $\begin{array}{c}8.06 \\
\pm 3.33\end{array}$ & 2.74 & \pm 1.13 \\
\hline & water & $\begin{array}{c}0.65 \\
\pm 0.19\end{array}$ & $\begin{array}{c}1.44 \\
\pm 1.00\end{array}$ & $\begin{array}{c}0.99 \\
\pm 0.35\end{array}$ & $\begin{array}{c}1.11 \\
\pm 0.15\end{array}$ & 4.93 & $\begin{array}{c}4.23 \\
\pm 0.11\end{array}$ & 2.23 & \pm 0.76 \\
\hline & DGT & 0.20 & 0.12 & 0.18 & 0.40 & 0.46 & 0.32 & 0.28 & \pm 0.13 \\
\hline \multirow[t]{3}{*}{$\mathrm{Zn}$} & biofilm & $\begin{array}{l}23.84 \\
\pm 6.35\end{array}$ & $\begin{array}{c}5.27 \\
\pm 5.56\end{array}$ & $\begin{array}{c}5.71 \\
\pm 4.74\end{array}$ & $\begin{array}{c}8.15 \\
\pm 8.20\end{array}$ & 44.46 & $\begin{array}{r}80.98 \\
\pm 4.29\end{array}$ & 28.07 & \pm 12.25 \\
\hline & water & 16.58 & 5.54 & 12.56 & 4.90 & 30.3 & 79.9 & 25.0 & \pm 11.6 \\
\hline & DGT & 5.26 & 5.44 & 3.82 & 4.24 & 12.49 & 13.59 & 7.47 & \pm 4.37 \\
\hline \multirow[t]{2}{*}{ As } & biofilm & $\begin{array}{c}1.696 \\
\pm 0.185\end{array}$ & $\begin{array}{c}0.508 \\
\pm 0.249 \\
\end{array}$ & $\begin{array}{c}0.888 \\
\pm 0.676\end{array}$ & $\begin{array}{c}0.420 \\
\pm 0.255 \\
\end{array}$ & 0.690 & $\begin{array}{c}1.507 \\
\pm 0.707 \\
\end{array}$ & 0.95 & \pm 0.22 \\
\hline & water & $\begin{array}{c}0.635 \\
\pm 0.184 \\
\end{array}$ & $\begin{array}{c}0.514 \\
\pm 0.023 \\
\end{array}$ & $\begin{array}{c}0.702 \\
\pm 0.033\end{array}$ & $\begin{array}{c}0.849 \\
\pm 0.334 \\
\end{array}$ & 1.326 & $\begin{array}{c}1.153 \\
\pm 0.222 \\
\end{array}$ & 0.86 & \pm 0.13 \\
\hline \multirow[t]{3}{*}{$\mathrm{Cd}$} & biofilm & $\begin{array}{c}0.218 \\
\pm 0.214\end{array}$ & $\begin{array}{c}0.098 \\
\pm 0.101\end{array}$ & $\begin{array}{c}0.122 \\
\pm 0.068\end{array}$ & $\begin{array}{c}0.133 \\
\pm 0.024\end{array}$ & 0.187 & $\begin{array}{c}0.440 \\
\pm 0.448\end{array}$ & 0.20 & \pm 0.05 \\
\hline & water & $\begin{array}{c}0.055 \\
\pm 0.029 \\
\end{array}$ & $\begin{array}{c}0.057 \\
\pm 0.033 \\
\end{array}$ & $\begin{array}{c}0.057 \\
\pm 0.025 \\
\end{array}$ & $\begin{array}{c}0.047 \\
\pm 0.061 \\
\end{array}$ & 0.058 & $\begin{array}{l}0.077 \\
0.083\end{array}$ & 0.06 & \pm 0.00 \\
\hline & DGT & 0.01 & 0.01 & 0.01 & 0.01 & 0.01 & 0.01 & 0.01 & \pm 0.001 \\
\hline \multirow[t]{3}{*}{$\mathrm{Pb}$} & biofilm & $\begin{array}{c}3.452 \\
\pm 1.129\end{array}$ & $\begin{array}{c}2.662 \\
\pm 1.836\end{array}$ & $\begin{array}{c}5.225 \\
\pm 0.238\end{array}$ & $\begin{array}{c}8.637 \\
\pm 1.626\end{array}$ & 7.207 & $\begin{array}{c}15.7 \\
\pm 14.4\end{array}$ & 7.15 & \pm 1.94 \\
\hline & water & $\begin{array}{c}0.370 \\
\pm 0.332\end{array}$ & $\begin{array}{c}0.589 \\
\pm 0.303\end{array}$ & $\begin{array}{c}0.413 \\
\pm 0.117\end{array}$ & $\begin{array}{c}0.381 \\
\pm 0.087\end{array}$ & 0.675 & $\begin{array}{l}0.751 \\
0.047\end{array}$ & 0.53 & \pm 0.07 \\
\hline & DGT & 0,09 & 0,07 & 0,05 & 0,08 & 0,08 & 0,08 & 0,08 & \pm 0.019 \\
\hline CCUw & & $\begin{array}{c}0.277 \\
\pm 0.169 \\
\end{array}$ & $\begin{array}{c}0.180 \\
\pm 0.099 \\
\end{array}$ & $\begin{array}{c}0.241 \\
\pm 0.154 \\
\end{array}$ & $\begin{array}{c}0.255 \\
\pm 0.194 \\
\end{array}$ & 0.540 & $\begin{array}{c}0.590 \\
\pm 0.146\end{array}$ & 0.339 & \pm 0.049 \\
\hline CCUb & & $\begin{array}{c}2.895 \\
\pm 0.551\end{array}$ & $\begin{array}{c}1.817 \\
\pm 0.578\end{array}$ & $\begin{array}{c}3.233 \\
\pm 0.286\end{array}$ & $\begin{array}{r}4.696 \\
\pm 0.552\end{array}$ & 4.457 & $\begin{array}{c}9.482 \\
\pm 3.255\end{array}$ & 4.428 & \pm 0.818 \\
\hline
\end{tabular}

$* \mathrm{n}=2$

686

687 Table 5. Metal concentration variables included in the RDA: metal concentration in biofilms

$688(\mu \mathrm{g} / \mathrm{g})$ and water $(\mu \mathrm{g} / \mathrm{L})$. For each site, values are the average and standard error of three

689 sampling. Average metal concentrations estimated with DGT $(\mu \mathrm{g} / \mathrm{L})$ were not included in the

690 RDA and are the average of two sampling. 


\begin{tabular}{|c|c|c|c|c|c|}
\hline \multirow[t]{2}{*}{ Code } & \multirow[t]{2}{*}{ Taxon } & \multicolumn{2}{|c|}{$\begin{array}{l}\text { Fraction of total } \\
\text { variance }\end{array}$} & \multicolumn{2}{|c|}{$\begin{array}{c}\text { Fraction of } \\
\text { explained } \\
\text { variance }\end{array}$} \\
\hline & & Environ. & Metals & Environ. & Metals \\
\hline GMIN & $\begin{array}{l}\text { Gomphonema minutum (Ag.) } \\
\text { Agardh }\end{array}$ & 37.02 & 7.38 & 83.4 & 16.6 \\
\hline GPAR & Gomphonema parvulum Kützing & 31.27 & 4.18 & 88.2 & 11.8 \\
\hline CPED & Cocconeis pediculus Ehrenberg & 33.56 & 5.83 & 85.4 & 14.6 \\
\hline NIFR & $\begin{array}{l}\text { Nitzschia frustulum (Kützing) } \\
\text { Grunow }\end{array}$ & 46.98 & 21.83 & 68.3 & 31.7 \\
\hline CMIN & $\begin{array}{l}\text { Cymbella minuta Hilse ex } \\
\text { orst\&Rabenh. }\end{array}$ & 39.66 & 33.9 & 53.9 & 46.1 \\
\hline AMIN & Achnanthes minutissima Kützing & 35.67 & 16.83 & 67.9 & 32.1 \\
\hline MVAR & Melosira varians Agardh & 33.27 & 32.77 & 50.4 & 49.6 \\
\hline NMEG & $\begin{array}{l}\text { Navicula menisculus Schuman var. } \\
\text { grunowii Lange-Bertalot }\end{array}$ & 33.14 & 44.87 & 42.5 & 57.5 \\
\hline GMIC & Gomphonema micropus Kützing & 29.77 & 26.66 & 52.7 & 47.2 \\
\hline CPLA & Cocconeis placentula Ehrenberg & 29.4 & 31.33 & 48.4 & 51.6 \\
\hline NCPR & Navicula capitatoradiata Germain & 27.42 & 35.83 & 43.3 & 56.6 \\
\hline NDIS & $\begin{array}{l}\text { Nitzschia dissipata (Kützing) } \\
\text { Grunow }\end{array}$ & 21.13 & 43.47 & 32.7 & 67.3 \\
\hline NGRE & Navicula gregaria Donkin & 11.52 & 42.08 & 21.5 & 78.5 \\
\hline APED & $\begin{array}{l}\text { Amphora pediculus (Kützing) } \\
\text { Grunow }\end{array}$ & 7.5 & 38.13 & 16.4 & 83.6 \\
\hline RABB & $\begin{array}{l}\text { Rhoicosphenia abbreviata } \\
\text { (C.Agardh) Lange-Bertalot }\end{array}$ & 6.57 & 28.19 & 18.9 & 81.1 \\
\hline NTPT & $\begin{array}{l}\text { Navicula tripunctata (O.F.Müller) } \\
\text { Bory }\end{array}$ & 3.32 & 28.05 & 10.6 & 89.4 \\
\hline NFON & Nitzschia fonticola Grunow & 2.98 & 23.48 & 11.3 & 88.7 \\
\hline $\mathrm{NSBH}$ & Navicula subhamulata Grunow & 2.56 & 37.07 & 6.5 & 93.5 \\
\hline NCTE & $\begin{array}{l}\text { Navicula cryptotenella Lange- } \\
\text { Bertalot }\end{array}$ & 2.19 & 38.73 & 5.3 & 94.6 \\
\hline
\end{tabular}

692

693

694

695

Table 6. Watershed study. Results of the partial canonical correspondence analysis (RDA) with forward selection of environmental variables. 


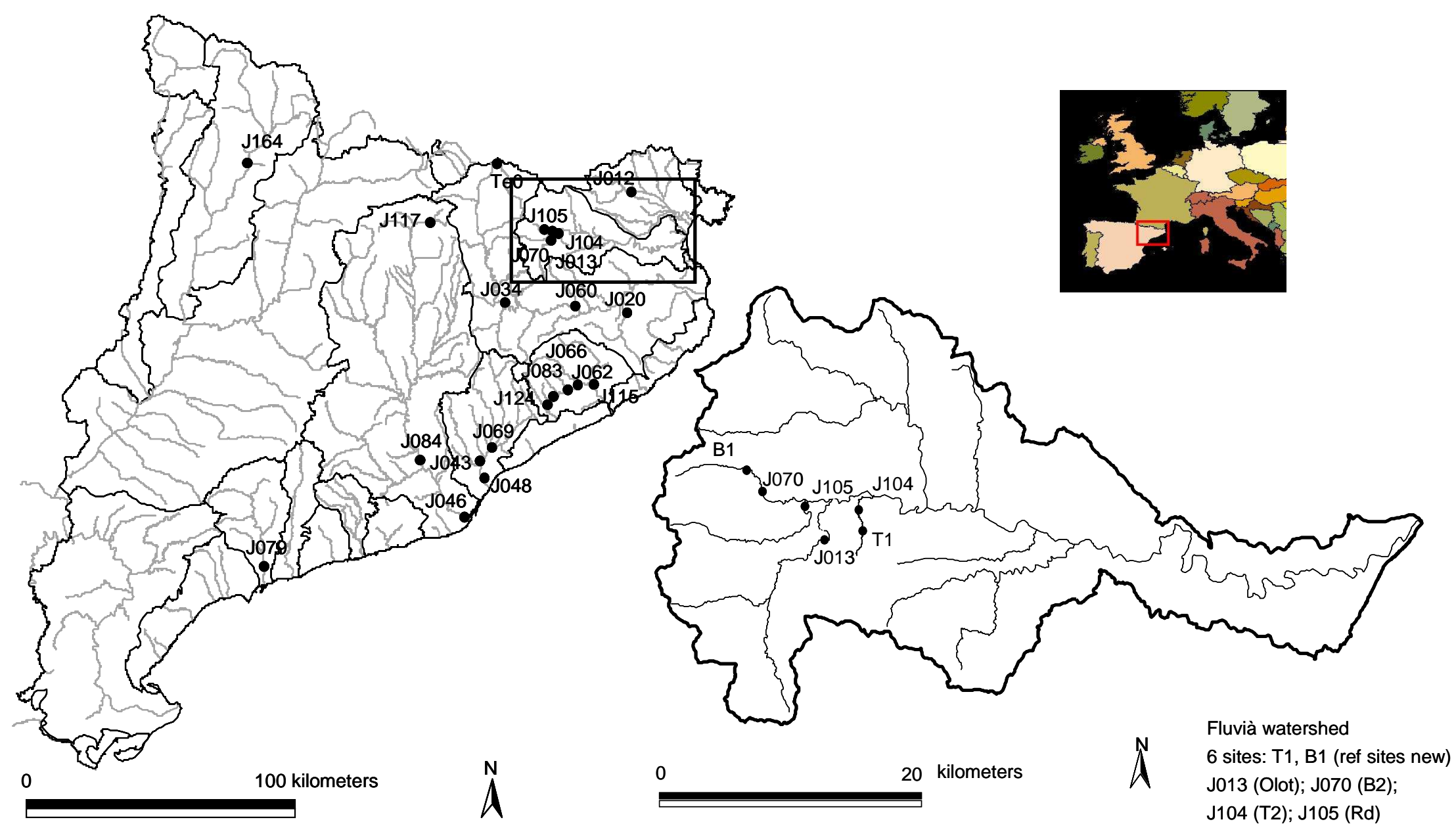

Figure 1. Location of the area of study (Catalonia, NE Spain). Study sites included in the regional and watershed studies (left and right maps, respectively). The code assigned by Catalan Water Agency. The location of the Fluvià watershed in the regional map is also indicated. 

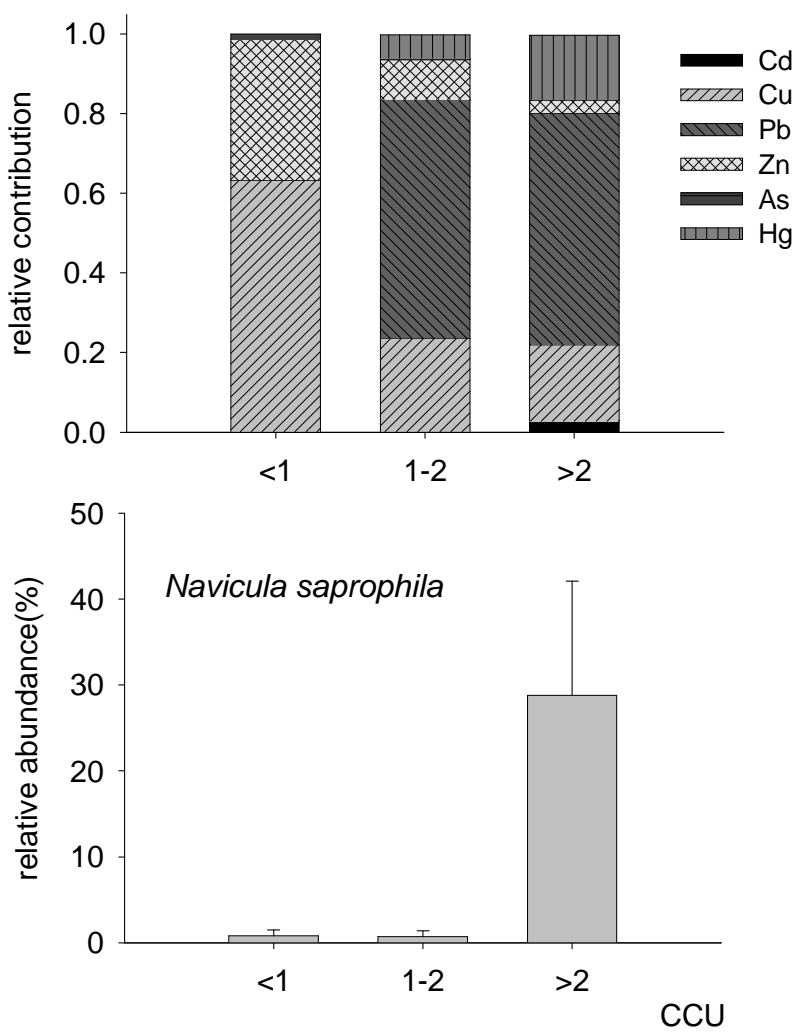

11 Fig 2. Regional case-study. Relative contribution of various metals to the cumulative criterion

12 unit (CCU) at background ( $\mathrm{CCU}<1, \mathrm{n}=10)$; low metal $(1<\mathrm{CCU}<2, \mathrm{n}=7)$; and medium metal

$13(2<\mathrm{CCU}<10, \mathrm{n}=8)$ categories. Average and standard error, for each metal category, of the

14 abundance of diatom taxon related to metal content. 

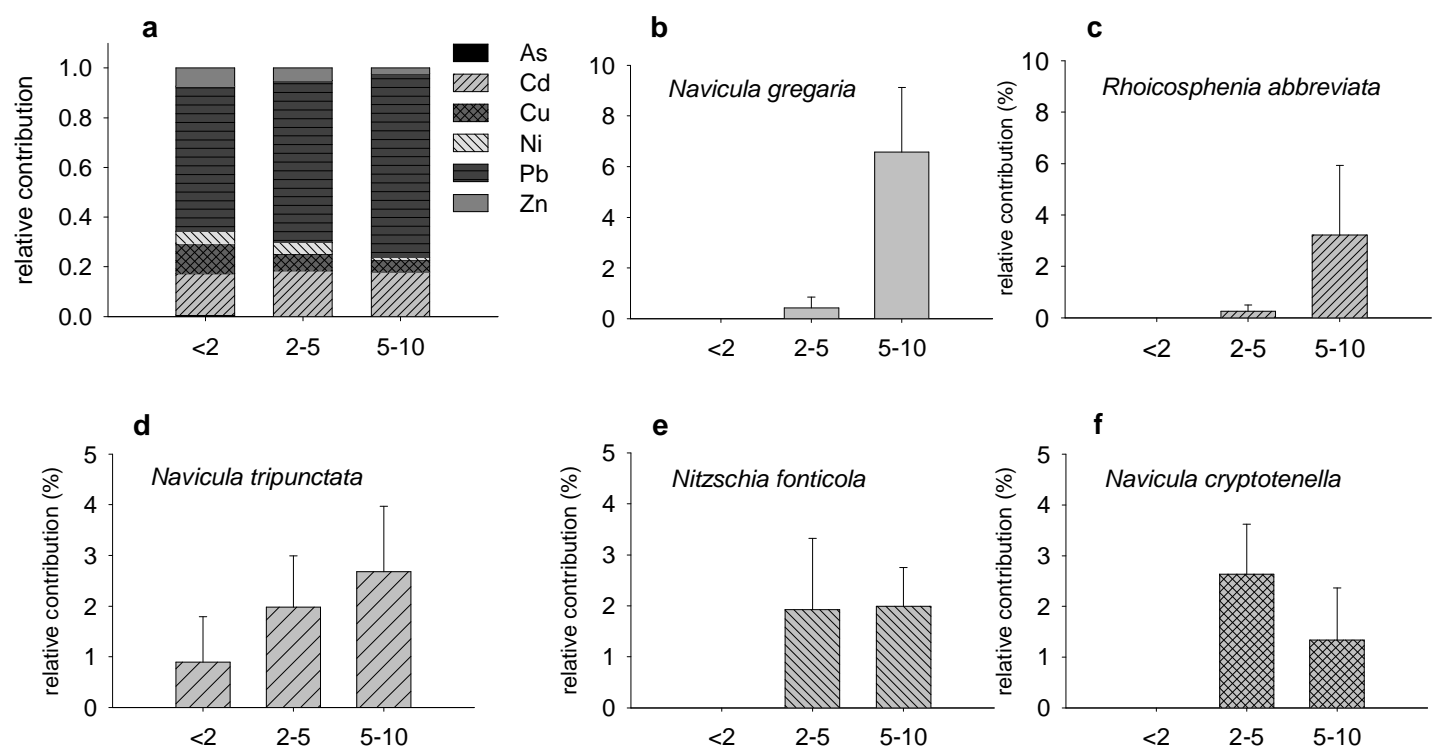

16

17

18

19

20

21

22

23 category, of the abundance of diatom taxa related to metal content. 